rechtsgeldige wijze - dat wil zeggen: in overeenstemming met de ter zake geldende wettelijke voorschriften (art. 585-590 Sv) alsmede de in de rechtspraak van de Hoge Raad tot uitdrukking gebrachte regels - is betekend, kan de rechter dat verzoek niet op die enkele grond afwijzen. Uit zo'n betekening volgt immers niet zonder meer dat de verdachte op de hoogte is van de zitting. In dat geval is een afwijzing van het verzoek tot aanhouding op de grond dat de aan dat verzoek ten grondslag gelegde omstandigheid niet aannemelijk is, alleen mogelijk indien op basis van andere omstandigheden kan worden vastgesteld dat de verdachte daadwerkelijk weet heeft van de zitting. Indien niet kan worden vastgesteld dat de verdachte daadwerkelijk weet heeft van de zitting, dient de rechter een afweging te maken tussen alle bij aanhouding van het onderzoek ter terechtzitting betrokken belangen. Bij die belangenafweging kan vervolgens wel betekenis toekomen aan de omstandigheid dat de dagvaarding of de oproeping voor de terechtzitting in hoger beroep op rechtsgeldige wijze, zij het niet in persoon, is betekend. Zoals tot uitdrukking is gebracht in HR 12 maart 2002, ECLI:NL:HR:2002:AD5163, r.o. 3.36-3.37, mag dan immers van de verdachte die hoger beroep instelt en prijs stelt op berechting op tegenspraak, worden verwacht dat hij de in het maatschappelijke verkeer gebruikelijke maatregelen neemt om te voorkomen dat de appeldagvaarding hem niet bereikt of de inhoud daarvan hem niet bekend wordt. Tot die maatregelen kan in elk geval worden gerekend dat de verdachte zich bereikbaar houdt voor zijn raadsman - die uit eigen hoofde een afschrift van de appeldagvaarding ontvangt indien hij zich in hoger beroep heeft gesteld - opdat de verdachte in voorkomende gevallen (ook) langs die weg van het tijdstip van behandeling van zijn zaak op de hoogte komt. Het kennelijk niet treffen door de verdachte van dergelijke in het maatschappelijke verkeer gebruikelijke maatregelen kan de rechter in hoger beroep - naast andere factoren die daarvoor van belang kunnen zijn, zoals het procesverloop en het gewicht van de zaak - in de vereiste belangenafweging betrekken.

In de onderhavige zaak heeft het hof met de overweging dat het verzoek door de raadsman 'niet deugdelijk' is onderbouwd, kennelijk als zijn oordeel tot uitdrukking gebracht dat de aan het verzoek tot aanhouding van het onderzoek ter terechtzitting ten grondslag gelegde omstandigheid dat de verdachte mogelijk geen weet heeft van de zitting, niet aannemelijk is. Dat oordeel was volgens de Hoge Raad niet begrijpelijk, in aanmerking genomen dat blijkens het verhandelde ter terechtzitting de oproeping in hoger beroep niet aan de verdachte in persoon is uitgereikt, terwijl het hof niet heeft vastgesteld dat de verdachte anderszins op de hoogte is geraakt van de datum van de zitting. Het hof had, bij die stand van zaken, dus de hiervoor weergegeven afweging moeten maken tussen alle bij aanhouding van het onderzoek ter terechtzitting betrokken belangen. Het hof heeft er echter geen blijk van gegeven die afweging te hebben gemaakt. De enkele omstandigheid dat volgens het hof in de periode tussen de zitting van 17 februari 2016 en die van 20 februari 2018 'geen (inhoudelijke) nieuwe stukken aan het dossier zijn toegevoegd, die een ander en/of nieuw licht werpen op hetgeen aan de verdachte is ten laste gelegd' kan een dergelijke afweging niet vervangen. Het middel slaagde dan ook.

\section{NTS 2020/46}

\section{HR 28 januari 2020, 19/00182, ECLI:NL:HR:} 2020:121

\begin{abstract}
OM-cassatie. Vrijspraak van opzettelijk onjuist/onvolledig doen van aangifte omzetbelasting en inkomstenbelasting op naam van medeverdachte en/of haar eenmanszaak (art. 69 AWR). Is het opzettelijk onjuist of onvolledig doen van een bij de belastingmet voorziene aangifte een kmaliteitsdelict zodat alleen een aangifteplichtige als pleger kan morden aangemerkt?
\end{abstract}

\section{Aantekening redactie}

De verdachte is door het hof vrijgesproken van het onder 1 en 2 tenlastegelegde en wegens ' 3 . medeplegen van het feit begaan, omschreven in artikel 68, eerste lid, onderdeel c, van de Algemene wet inzake rijksbelastingen, terwijl het feit ertoe strekt dat te weinig belasting wordt geheven, meermalen gepleegd' veroordeeld tot een taakstraf voor de duur van 40 uren subsidiair 20 dagen hechtenis. Het middel van het openbaar ministerie klaagde dat het oordeel van het hof dat de verdachte niet als pleger van het hem onder 1 en 2 tenlastegelegde kan worden aangemerkt blijk gaf van een onjuiste rechtsopvatting, althans onbegrijpelijk was.

In deze zaak ging het om de heffing van belasting op de omzet van en de inkomsten uit een winkel. De winkel (A) is een eenmanszaak en wordt gevoerd op naam en voor rekening van de vrouw van verdachte. Verdachte doet (in de hier relevante periode) de administratie en verzorgt de belastingaangiften. De verdachte heeft verklaard dat de administratie niet op orde was en dat daardoor de aangiften ook niet klopten. Het middel bestrijdt de motivering van de vrijspraak voor de feiten 1 en 2 voor zover deze inhoudt dat verdachte 'zelf niet verplicht was tot het doen van de in de tenlastelegging genoemde aangiften'. Het hof heeft de verdachte van deze feiten vrijgesproken en daartoe het volgende overwogen:

'Onder de feiten 1 en 2 wordt de verdachte - kort gezegd - verweten dat hij zich samen met de medeverdachte, althans alleen, heeft schuldig gemaakt aan 
het opzettelijk doen van onjuiste of onvolledige belastingaangiften op naam van de medeverdachte en/of A, strafbaar gesteld bij artikel 69, tweede lid, van de Algemene wet inzake rijksbelastingen (hierna: AWR). Uitgangspunt is dat de strafbepaling van artikel 69, tweede lid, van de AWR zich richt tot de angifteplichtige en dat anderen slechts als deelnemer aan het door de aangifteplichtige begane delict kunnen worden aangemerkt (vgl. Hoge Raad 17 oktober 2006, LJN AU8286, NJ 2006, 575). Dat ook een onverplichte, niet op uitnodiging van de inspecteur gedane, aangifte binnen het bereik van deze strafbepaling kan vallen (ECLI:NL:HR:2011:BP3746 en ECLI:HR: 2011:BQ3673) maakt dat niet anders. De verdachte is ten aanzien van het onder 1 en 2 ten laste gelegde niet aan te merken als aangifteplichtige, terwijl ook niet is gebleken dat hij met de aangifteplichtige vereenzelvigd moet worden, zodat hij niet binnen het bereik van de strafbepaling valt. Aan de verdachte is echter wel het medeplegen van het opzettelijk onjuist doen van aangifte ten laste gelegd. De andere (mede)pleger betreft hier dan de aangifteplichtige, de medeverdachte. Het hof overweegt als volgt. Voor medeplegen is vereist dat de verdachte het delict in bewuste nauwe samenwerking met een ander heeft begaan. Dit houdt in dat vastgesteld moet worden dat de medeplegers opzettelijk - willens en wetens - samenwerken tot het verrichten van de ten laste gelegde gedraging(en). Alhoewel niet alle medeplegers uitvoeringshandelingen hoeven te verrichten ten aanzien van het gronddelict, moet er sprake zijn van opzet op de samenwerking en moet de samenwerking van voldoende gewicht zijn. Bij arrest van 15 juni 2018 van dit hof is de medeverdachte vrijgesproken van het medeplegen van de onder 1 en 2 ten laste gelegde feiten. Naar het oordeel van het hof kan op basis van de stukken en het verhandelde ter terechtzitting niet worden vastgesteld dat de medeverdachte (voorwaardelijk) opzet heeft gehad op het onjuist of onvolledig doen van de onder 1 en 2 ten laste gelegde aangiften. Dit staat ook in de zaak van de verdachte in de weg aan de voor een bewezenverklaring vereiste vaststelling van een bewuste samenwerking tot het onjuist of onvolledig doen van de onder 1 en 2 ten laste gelegde aangiften (ECLI:NL:HR:2005:AU2246, NJ 2007, 455). Het medeplegen door de verdachte met de belastingplichtige kan onder deze omstandigheden niet worden bewezen. $N u$ de verdachte zelf niet verplicht was tot het doen van de in de tenlastelegging genoemde aangiften, moet hij van het onder 1 en 2 ten laste gelegde morden vrijgesproken. Het hof merkt over de strafrechtelijke aansprakelijkheid ter zake van het handelen van de verdachte op dat valsheid in geschrift niet aan de verdachte ten laste is gelegd.'

Aan het middel is ten grondslag gelegd dat in de overweging van het hof dat de verdachte niet binnen het bereik van artikel 69 lid 2 AWR valt omdat hij niet als aangifteplichtige is aan te merken als zijn oordeel besloten ligt dat het opzettelijk doen van een onjuiste of onvolledige belastingaangifte, zoals strafbaar gesteld bij artikel 69 lid 2 AWR, een impliciet kwaliteitsdelict is. Volgens de steller van het middel volgt uit HR 5 juli 2011, ECLI:NL:HR:2011:BP3746, HR 12 juli 2011, ECLI:NL:HR:2011:BQ3673 en HR 16 september 2014, ECLI:NL:HR:2014:2784, echter dat naar huidig inzicht ook degene die voor een ander opzettelijk een belastingaangifte onjuist of onvolledig doet zich als pleger schuldig kan maken aan een overtreding van artikel 69 lid 2 AWR. Voor een veroordeling wegens het plegen van het in die bepaling omschreven aangiftedelict is dus niet vereist dat de verdachte zelf de hoedanigheid van aangifteplichtige heeft, zodat geen sprake is van een impliciet kwaliteitsdelict, aldus de steller van het middel. Artikel 69 lid 2 AWR luidt als volgt:

'Degene die opzettelijk een bij de belastingwet voorziene aangifte onjuist of onvolledig doet, dan wel het feit begaat, omschreven in artikel 68, eerste lid, onderdeel c, wordt, indien het feit ertoe strekt dat te weinig belasting wordt geheven, gestraft met gevangenisstraf van ten hoogste zes jaren of geldboete van de vijfde categorie of, indien dit bedrag hoger is, ten hoogste eenmaal het bedrag van de te weinig geheven belasting, met dien verstande dat voor zover de onjuistheid in of onvolledigheid van de aangifte betrekking heeft op belastbaar inkomen als bedoeld in artikel 5.1 van de Wet inkomstenbelasting 2001 de geldboete ten hoogste driemaal het bedrag van de te weinig geheven belasting bedraagt.'

Uit de tekst van deze bepaling volgt niet dat de delictsomschrijving zich wat betreft het opzettelijk onjuist of onvolledig doen van een bij de belastingwet voorziene aangifte richt tot personen met een bepaalde hoedanigheid. Het kwam aldus aan op de vraag of bijvoorbeeld uit de wetsgeschiedenis en/of de wetssystematiek volgt dat voor het plegen van dit delict een bepaalde hoedanigheid nodig is. In dat geval zou sprake zijn van een impliciet kwaliteitsdelict. ${ }^{35}$ De Hoge Raad beantwoordde deze vraag ontkennend, nu artikel 69 lid 2 AWR is gericht tot degene die een 'bij de belastingwet voorziene aangifte' onjuist of onvolledig doet. Als pleger van het onjuist of onvolledig doen van een bij de belastingwet voorziene aangifte moet daarom worden aangemerkt degene die tot het doen van de aangifte gehouden is. ${ }^{36}$ Die gehoudenheid tot het doen van aangifte kan worden vastgesteld bij eenieder die tot het doen van aangifte is uitgenodigd als voorzien in artikel 8 lid 1 AWR.

De omstandigheid dat de in artikel 8 lid 1 AWR bedoelde uitnodiging tot het doen van aangifte (nog) niet was ontvangen, staat op zichzelf beschouwd niet in de weg

35. Een kwaliteitsdelict wil zeggen dat de pleger een specifieke 'kwaliteit' moet bezitten om het delict te kunnen plegen. Een voorbeeld hiervan is art. $359 \mathrm{Sr}$ (verduistering door een ambtenaar). leder ander die zich schuldig maakt aan verduistering kan worden vervolgd op grond art. $321 \mathrm{Sr}$ waarin de 'normale' verduistering strafbaar is gesteld.

36. Vgl. over een geval waarin deze aangifteplicht rustte op een vennootschap en derhalve niet op de persoon die namens de vennootschap de aangifte feitelijk had gedaan: HR 17 oktober 2006, ECLI:NL:HR: 2006:AU8286 
aan het oordeel dat sprake is van een 'bij de belastingwet voorziene aangifte' in de zin van artikel 69 lid 2 AWR. ${ }^{37}$ Een als aangifte ingediende gegevensdrager kan uitsluitend worden aangemerkt als een 'bij de belastingwet voorziene aangifte' indien die aangifte is gedaan door degene op wiens belasting- of betalingsplicht die aangifte betrekking heeft, of door degene die uit hoofde van artikel 42 tot en met 44 AWR als vertegenwoordiger van de belasting- of betalingsplichtige kan optreden. Het middel ging uit van de opvatting dat ook buiten deze gevallen sprake kan zijn van het als pleger strafrechtelijk aansprakelijk zijn voor het onjuist of onvolledig doen van een bij de belastingwet voorziene aangifte als bedoeld in artikel 69 lid 2 AWR. Deze opvatting is dus onjuist. De Hoge Raad merkt voorts nog op dat artikel 47 tot en met $51 \mathrm{Sr}$ diverse mogelijkheden bieden om degene die anders dan als pleger betrokken is bij het onjuist of onvolledig doen van een bij de belastingwet voorziene aangifte, onder specifieke voorwaarden strafrechtelijk aansprakelijk te stellen voor die betrokkenheid. Onder omstandigheden kan een dergelijke gedraging ook opleveren het in artikel 225 lid 2 Sr strafbaar gestelde ('valsheid in geschrift'), welke delictsomschrijving tot eenieder is gericht.

\section{NTS 2020/47}

HR 21 januari 2020, 18/01333, ECLI:NL:HR: 2020:44

Opzettelijk dreigend teksten en foto's per e-mail te sturen naar A. Bedreiging a.b.i. art. 285.1 Sr?

\section{Aantekening redactie}

Volgens vaste rechtspraak is voor een veroordeling ter zake van bedreiging met enig misdrijf tegen het leven gericht onder meer vereist dat de bedreigde daadwerkelijk op de hoogte is geraakt van de bedreiging en de bedreiging van dien aard is en onder zodanige omstandigheden is geschied dat bij de betrokkene in redelijkheid de vrees kon ontstaan dat deze het leven zou kunnen verliezen ${ }^{38}$ en dat het opzet van de verdachte daarop was gericht. ${ }^{39}$ In deze zaak is de verdachte door het hof wegens (o.m.) 'bedreiging met enig misdrijf waardoor gevaar voor de algemene veiligheid van

37. Vgl. HR 5 juli 2011, ECLI:NL:HR:2011:BP3746 en HR 12 juli 2011, ECLI:NL:HR:2011:BQ3673.

38. Vgl. HR 7 juni 2005, ECLI:NL:HR:2005:AT3659.

39. VgI. HR 17 januari 1984, ECLI:NL:HR:1984:AC8252 personen of goederen ontstaat en met enig misdrijf tegen het leven gericht en met brandstichting' veroordeeld tot drie maanden gevangenisstraf, voorwaardelijk met een proeftijd van twee jaar, en tot een taakstraf voor de duur van 150 uur, subsidiair 75 dagen hechtenis. Het hof had bewezen verklaard dat de verdachte:

'op 3 februari 2015 te Amsterdam iedere politieagent die bij verdachte komt heeft bedreigd met:

- enig misdrijf waardoor gevaar voor de algemene veiligheid van personen en goederen ontstaat, en

- enig misdrijf tegen het leven gericht, en

- brandstichting,

immers heeft verdachte opzettelijk dreigend teksten en foto's per e-mailbericht naar [getuige] verzonden, te weten:

"Maar jullie kunnen mij niet uitlokken want ik zit in mijn bunker met 15 liter benzine en twee butaan gasflessen van 50 liter per stuk. Iedere huurmoordenaar en politieagent zal worden opgeblazen die hier komt.",

"[getuige], Thet wanna fuck with me? They fucking with the best. I take them all to fucking hell. Who? Me! That's who. Ik zal het complete gebouw opblazen wanneer ik maar één verdacht persoon of politieagent zie. Ik heb een gijzelaar en ze kunnen die jongen terugkrijgen wanneer ik een miljoen euro krijg en de liquidatieopdracht is ingetrokken. [betrokkene 1] heeft mij een Uzi gebracht en [betrokkene 2] twee handgranaten. Jij gaat de politie geen informatie geven dat ik bezig ben met mijzelf verdedigen en met een 'schoonmaak' en [betrokkene 3] kan dat beter ook niet doen. Ik ga iedereen in dit conflict vermoorden en daarna ga ik mijzelf en het gebouw opblazen.",

"Politie bellen is zinloos. Ik heb mij al verplaatst maar het gebouw is één boobytrap. Wanneer jij de politie informeert heb jij een explosie veroorzaakt.",

een foto met daarop afgebeeld een bed met daarop liggend een paspop afgedekt met een jas, en

twee foto's met daarop afgebeeld twee gasflessen aan elkaar verbonden door een elektriciteitssnoer met daaraan gekoppeld een mobiele telefoon, geplaatst voor een voordeur,

terwijl deze bedreiging schriftelijk en onder bepaalde voorwaarden is geschied.'

Het middel klaagde over de bewezen verklaarde bedreiging. Aangevoerd werd dat:

- het vreesobject 'iedere politieagent die bij verdachte komt' niet voldoende bepaald is;

- uit de bewijsvoering niet volgt dat de bewezen verklaarde bewoordingen bij 'iedere agent die bij verdachte komt' de redelijke vrees hebben kunnen doen ontstaan voor het in het vooruitzicht gestelde gevolg; 